\title{
Speech Acts in EFL Classrooms
}

\author{
Danin Christianto* \\ REAL Equivalent English \\ E-mail: nikolausdaninchristianto@gmail.com
}

*(Corresponding Author)

DOI: https://doi.org/10.1836/jopr.v2i1.68-79

Submission
Track:
Received:
18-03-2020
Final Revision:
03-04-2020
Available online:
06-04-2020
Corresponding
Author:
Danin Christianto
nikolausdaninchristianto@gmail.com

\begin{abstract}
Speech act is a functional unit in the form of an act which helps humans understand or accomplish things with words in communication. This research was aimed to find out and analyse the types of speech acts which were performed by teachers and students in English as a Foreign Language (EFL) classrooms. The researcher employed the speech act theory from Cruse (2000) to analyse and interpret the research results. Qualitative research was applied in this research due to the data source was from the teaching and learning activities in naturalistic environments in English classrooms. The subjects of this research were teachers and students in REAL Equivalent English classrooms. The results showed that there were three types of speech acts found in the interactions between the teachers and students, namely locutionary act, illocutionary act, and perlocutionary act. Locutionary act was performed when teachers and students uttered expressions with no certain intentions. Illocutionary act, on the other hand, was performed when the expressions contained certain intentions to listeners. Perlocutionary act was performed when the listeners showed responses and acted as feedback to the speakers' utterances. By conducting this research, the researcher hopes that it can give more insights to readers regarding to the study of speech act theory in pragmatics field.
\end{abstract}

Keywords: English as a Foreign Language (EFL) Classrooms, Speech Acts, REAL Equivalent English, Teachers and Students. 


\section{INTRODUCTION}

Language is one of the important devices which is used by almost every human being to build a communication to each other. According to Aitchison (2003), language can be used to "communicate feelings and emotions", which means that language has various functions instead of only for talking. Humans are similar to other primates, meaning that they are able to convey emotions through gestures, screams, sobs, and grunts, for example. O'Grady, Dobrovolsky, and Katamba (1989) states that language is "a system of communication, a medium for thought a vehicle for literacy expression, a social institution, a matter for political controversy, and a factor in nation building" (p. 1). Besides, language can allow human beings to learn and adapt to changing circumstances far more quickly than would be achieved by evolution (Poole, 1999). In short, it can be concluded that language is very important since it makes any kinds of communications possible.

In language, there are many various structures or systems within. Some say that the systems are quite complicated due to their complexity and wide range of language units and components. There are four basic units which are needed to use language, mainly sound, word, sentence, and meaning. Linguists tend to study each unit which then is divided into separated fields. First, the field which studies sound is called Phonetics and Phonology. Second, the field which studies word is Morphology. Third, the field which studies sentence is Syntax. Last but not least, the field which studies meaning is called Semantics. All of those units are required in the language usage as they can build communications. There is, however, one more field in linguistics which is considered into the study of meaning as well. This is called pragmatics.

Pragmatics is one of the outer linguistic ring branches which tries to study the meaning in context or speaker's meaning. As stated by Yule (1996), that pragmatics is "the study of speaker meaning as distinct from word or sentence meaning" (p. 133). This means that this field deals with how speakers use language in ways which are unpredictable from linguistic knowledge alone (Aitchison, 2003). In a narrow sense, it deals with how listeners arrive at the intended meaning of speakers. This is similar to Fromkin, Rodman, and Hyams' (2017) definition, which states that "pragmatics is the study of how context and situation affect meaning" (p. 498). There are a lot of various things which can be researched in pragmatics. One of them is the use of speech act. 
Speech act, in pragmatics, is a part of communication which can be defined as an action which is performed by the use of an utterance to communicate. Dawson and Phelan (2016) define speech act as "actions that are performed only through using language" (p. 710). It means that speech act describes the use of speech which emphasise the speaker's intention or goal in producing an utterance. There are broad ranges of things which can be analysed from speech acts. Previous researchers had conducted various research of it with different contexts. In this research, the researcher would like to analyse the use of speech acts in English as a Foreign Language (EFL) classrooms.

The reason why the researcher wanted to conduct research on speech act is because there are a lot of things which can be analysed from interactions and utterances, especially in English classrooms. The speech act in the classrooms involve all verbal utterances which is employed as a medium in classroom communication. Researching speech acts in the teaching and learning process is known as discourse analysis. Due to the issue, this research focused on classroom interactions during the teaching and learning process in REAL Equivalent English of Yogyakarta.

REAL Equivalent English is a private English course which was established in 2003 by a businessman named Ir. Handojo Mawardi and his assistants named Daniel Batey and Moniq Van Devard. The English course was built to give an alternation in teaching English by using native English speakers as the teachers. The purpose of this course is to be a colleague in introducing English to the society without putting aside the development of other aspects, and to create a condusive, healthy, and enjoyable learning environment for students. Currently, there are various programs which are offered in this course in order to help learners develop their English skills based on their needs, namely REAL EGP (English for General Purposes: Kids, Teens, Adults), REAL Conversation (Teens, Adults), REAL Business, REAL TOEFL PBT, REAL TOEFL ITP, REAL TOEFL IBT, IELTS, TOEIC, GRE, SAT, and GMAT (Christianto, 2019). 
Previously, there were several research on linguistic pragmatics which mainly focused on the use of speech acts in different contexts. The first one was the research from Jakob (2018) in his article entitled "Speech Acts in EFL Classroom at Islamic Senior High School (MAN) 1 Sinjai". The research was aimed to observe the use of speech acts by teachers and students in their interactions in EFL classroom. The results showed that there were three types of speech acts which were found in the interactions between the teachers and students, namely locutionary act, illocutionary act, and perlocutionary act. Locutionary act was performed by the teachers when they were greeted by students. Illocutionary act was found when the teachers asked the students to read some paragraphs in the book. Lastly, perlocutionary act was committed when the teachers asked the students to be quiet since it was in the classrooms.

Second, the research which was entitled "An Analysis of Directive Speech Act Found in 'Koi Mil Gaya' Movie" was conducted by Fitria (2019). Another speech act analysis was done here, focusing more on finding out the types of directive speech acts and which directive speech acts were more frequently used in "Koi Mil Gaya" movie. Qualitative methodology, as well as documentary study, was employed to analyse and interpret the collected data. The results of the study were 246 utterances of directive speech act were produced by the characters in the movie. The forms of the directive speech acts were found in utterances which contained words, phrases, clauses, and sentences. Aside of that, the research also showed that the movie contained three aspects, namely command, request, and suggestion. In command, there were 165 data or $84,18 \%$. In suggestion, there were 20 data or $10,20 \%$. In request, there were 11 data or $5.61 \%$. Therefore, it was concluded that the most frequent type of directive speech act was in command.

Third, the speech act research was conducted by Basra and Thoyyibah (2017) in their research entitled "A Speech Act Analysis of Teacher Talk in an EFL Classroom". Here, the researchers attempted to find out the speech act classification which was mostly used by an EFL teacher while teaching. The research was classified into case study research which involved an English teacher who was teaching in an EFL classroom. It used Searle's taxonomy of speech act classification as the instrument. The findings of the research showed that the frequency each classification was found as the following: $70 \%$ for directive, $21 \%$ for representative, $6 \%$ for expressive, and 3\% for commissive. Directive speech acts were used mostly by the teacher for the teacher applied the principle of Communicative Language 
Teaching. The use of directive speech act made implication towards the improvement of students' productive skills. Thus, the researchers concluded that the choice of the speech act classification would determine the teaching approach.

Fourth, the research was done by Merdana, Seken, and Putra (2013) in their research entitled "An Analysis of Speech Acts Produced by Elementary School Teachers and Students to Facilitate Teaching and Learning at SDN Pringgasela East Lombok”. It was aimed to describe, analyse, and explain types, functions, instructional functions of speech acts produced, and politeness strategies employed in the classroom. Teachers and students became the subjects of the research. The data of the research were collected through observation, interview, and note taking which then were analysed by following Miles and Huberman's (1994) interactive cyclical model. As the results, the researchers found that teachers produced more utterances $(72,59 \%)$ than students did $(27,41 \%)$.

Fifth, the research was conducted by Altikriti (2011) in the article entitled "Speech Act Analysis to Short Stories". In the study, the researcher aimed to analyse the types of speech acts from three different short stories. The speech act theories from Sadock (1974) and Green (1975) were employed to support the findings of the research. The results showed that there were two types of speech acts found in each short story, which were Direct Speech Act and Indirect Speech Act. They were divided into three parts; Text One, Text Two, and Text Three. In Text One, there were 99 (47\%) Direct Speech Acts and 1 (0,47\%) Indirect Speech Act out of 212 utterances. In Text Two, there were 56 (44\%) Direct Speech Acts and $1(0,78 \%)$ Indirect Speech Act out of 127 utterances. Lastly, in Text Three, there were $142(0,46 \%)$ Direct Speech Acts and $0(0 \%)$ Indirect Speech Act out of 212 utterances. In conclusion, the researcher realized that the use of speech acts fluctuated in both quantity and type from one writer to another and from one theme to another.

Based on the explanation above, the researcher aimed to investigate two problems, mainly the types of speech acts which were used by teachers and students and the functions of 
the speech acts produced by the teachers and students. Through this research, the researcher hopes that it can give more insights to readers concerning to the study of speech act theory in pragmatics field.

\section{RESEARCH METHOD}

In this research, the researcher employed qualitative research methodology. This methodology uses description rather than number in terms of interpreting data and results. Dörnyei (2007) says "qualitative research involves data collection procedures that result primarily in open-ended, non-numerical data which is then analysed primarily by nonstatistical methods" (p. 24). This means that qualitative research study things in their natural settings which attempt to make sense of phenomena in terms of the meanings that people bring to them. Generally, it is begun with assumptions, a worldview, the possible use of a theoretical lens, and the study of research problems inquiring into the meaning individuals or groups ascribe to a social or human problem (Creswell, 2007).

The method which was applied in this research was case study. According to Ary, Jacobs, Sorensen, and Razavieh (2010), "case study is a type of ethnographic research study that focuses on a single unit, such as one individual, one group, one organisation, or one program" (p. 29). This research attempted to find out and analyse the types of speech acts which were performed by teachers and students in English as a Foreign Language (EFL) classrooms. The researcher would observe the utterances and recorded them naturally.

The data of this research were utterances which were produced by teachers and students in EFL classrooms in REAL Equivalent English Yogyakarta. There were three steps which were done by the researcher in collecting the data. The first step which the researcher did was recording the interactions between teachers and students for three meetings in classrooms. The second step was the data collected were transcribed in the form of audio. The last step was the researcher analysed and compared the speech acts occurred within the interactions in the classrooms. To analyse the types of speech acts, the researcher employed the theory from Cruse (2000) as the main theory to relate the results with it.

\section{RESULTS \& DISCUSSION}


In this section, the researcher discussed about the results of the research which focused on analyzing the types and functions of speech acts between teachers and students employed in English as a Foreign Language (EFL) classrooms which were situated in REAL Equivalent English Course, Yogyakarta. Based on the observations, the researcher found out that there were three types of speech acts, namely Locutionary Act, Illocutionary Act, and Perlocutionary Act. Each result was elaborated as below.

\section{A. Locutionary Act}

Locutionary Act is an act of which the speaker produces utterances which contain certain noises, certain words in a certain construction, and utterances with a certain sense and a certain reference (Cruse, 2000). The researcher found two examples of locutionary act which were used in the interactions in the classroom.

\section{Data 1}

Teacher: "Hello, Farrel. What happened? Why do you look so sad?"

Student: "What happened on you actually?"

Teacher: "'What happened to you', not 'What happened on you?',

Student: "Okay, Miss!"

From data 1 above which was taken from the fourth meeting of the transcription., it can be seen that the teacher performed a locutionary act when she asked "Hello, Farrel. What happened? Why do you look so sad?" to her student. The teacher performed an action to ask Farrel, one of her students, about his condition. The utterance that she produced, thus, contained literal meaning to communicate with the students. Aside of that, the researcher also found another example of the use of locutionary act as below. 


\section{Data 2}

Teacher: "How is life?"

Student: "I'm great! And you?"

Teacher: "I'm fine, too. Thank you. Now, Stefi, can you please take the Impact On English textbooks in the library?"

Data 2 showed another example of the use of locutionary act, which indicated that the teacher asked the students' condition by saying "How is life?". Such an utterance contained a communicative meaning when the teacher gave a greeting to the students. Literally, the utterance does not need a reply from the students.

\section{B. Illocutionary Act}

Illocutionary Act is an act which has social functions of what are said by speakers. There are several types of acts which are considered as illocutionary act, namely bequeathing, promising, and ordering (Cruse, 2000). The data below showed the results of the use of illocutionary act in REAL Equivalent English Classroom. There were two examples which were found in the interaction between the teacher and students in the classroom during the teaching and learning process.

\section{Data 3}

Teacher: "First, we are going to talk about giving directions. So, the first thing that we will discuss is the directions".

Student: "Okay!"

From data 3 above, it can be seen that the teacher employed an illocutionary act by saying "First, we are going to talk about giving directions. So, the first thing that we wil discuss is the directions". The expression was used by the teacher in order to convey her intention that the first thing they were going to learn was about directions. Also, this expression contains a 
social function which can be used to give a command to someone. Another example can be seen as below.

\section{Data 4}

Teacher: "Have a sit, please. Feli, please take your friends' work on my table". Student: "No problem, Miss".

In data 4 , the teacher asked the students to sit down by saying "Have a sit, please". This kind of expression has a certain intention as a command to the students to have a sit. Therefore, it is considered as illocutionary act since it contains a social function within the expression. Aside of that, the expression of "Feli, please take your friend's work on my table" also contains a social function within and it was employed by the teacher to ask one of the students to submit her friends' work to the teacher's table. Thus, this is also categorised as illocutionary act.

\section{Perlocutionary Act}

Perlocutionary act is considered as an act which is employed in order to produce a further effect for the hearer. Acts like persuading someone to do something, or getting them to believe in something are the common examples of perlocutionary act (Cruse, 2000). Also, this act has a social function in the utterance and feedback by the listener as a response to what the speaker says.

There were two examples of the use of perlocutionary act which were found during the teaching and learning process in the REAL English classrooms. The examples are as below.

\section{Data 5}

Teacher : "Alright, Shannon and Farel, please come to the front of the class". 
Students $\quad$ : (Preparing to come to the front of the class)

According to data 5 above, the teacher asked the students to come to the front of the class by saying "Alright, Shannon and Farel, please come to the front of the class". Such an expression is considered as a perlocutionary act since the students did what the teacher said. There was a response from the listeners to do what was commanded by the speaker. Thus, the example of perlocutionary act can be seen in data 5 above where the students gave a response by preparing themselves to come to the front of the class. Another example of the use of perlocutionary act is like below.

\section{Data 6}

Teacher

: “Khomey, you know how to ride a motorcycle, don't you? Please tell and show us how to do it in front of the class".

Student $\quad$ : (Coming to the front of the class and pretending as if he was riding a motorcycle).

In data 6 above, the teacher asked one student to come to the front of the class by saying "Khomey, you know how to ride a motorcycle, don't you? Please tell and show us how to do it in front of the class". In this expression, there was a certain intention that the teacher would like her student to do the thing that she had said. She gave the command and then the student started to do it, which was pretending to ride a motorcycle. Therefore, the expression is classified as a perlocutionary act as it has a particular intention within the expression and the listener.

\section{CONCLUSION}

Speech act is an important mean which can be used to recognize or understand various utterances meanings such as apology, greeting, request, complaint, invitation, compliment, or refusal. In classrooms, particularly, speech act plays an important role since the proper use of it can make the teaching and learning process run well. Interactions between teachers and students contain a lot of different types of speech acts. From the research which had been conducted by the researcher in REAL Equivalent English classrooms, it was found that there 
were three types of speech acts employed by the teachers and students, namely locutionary act, illocutionary act, and perlocutionary act. First, the example of locutionary act was when the teacher was greeted by the students since the teacher's expression did not have any particular intention. Second, the example of illocutionary act was when the teacher asked one of her students to have a sit because it contained a certain intention. Lastly, the example of perlocutionary act was when the teacher asked one student to perform how to ride a motorcycle in front of the class. This case was different to illocutionary act as the listener gave a feedback which was considered as a response to what the speaker had said. This kind of research is addressed to teachers and students in order to build better perspectives on the use of various speech acts and their examples. Through this research, there are some things that the researcher wishes regarding the use of speech act. The first one is that the researcher hopes that by studying this research, classroom communications and interactions become better during the teaching and learning process. The second one is that the researcher hopes that there will be another speech acts research which is conducted quantitatively since this research is considered as qualitative. The last one is that this research can help language learners or linguists who are willing to study further about speech acts, particularly in the Linguistic Pragmatic field.

\section{REFERENCES}

Aitchison, J. (2003). Teach yourself: Linguistics. London: Hodder \& Stoughton, Ltd.

Altikriti, S. F. (2011). Speech act analysis to short stories. Journal of Language Teaching and Research, 2(6), 1374-1384.

Ary, D., Jacobs, L. C., Sorensen, C., \& Razavieh, A. (2010). Introduction to research in education ( $8^{\text {th }}$ ed.). Belmont: Wadsworth.

Basra, S. M. \& Thoyyibah, L. (2017). A speech act analysis of teacher talk in an EFL classroom. International Journal of Education, 10(1), 73-81. 
Christianto, D. (2019). Teachers' perceptions on the use of the communicative language teaching approach in the English classrooms. International Journal of Indonesian Education and Teaching, 3(1), 90-101.

Creswell, J. W. (2007). Qualitative inquiry \& research design: Choosing among five approaches ( $2^{\text {nd }} \mathrm{ed}$.). Thousand Oaks: Sage Publications, Inc.

Cruse, D. A. (2000). Meaning in language: An introduction to semantics and pragmatics. New York: Oxford University Press.

Dawson, H. C. \& Phelan, M. (2016). Language files: Materials for an introduction to language and linguistics $\left(12^{\text {th }} \mathrm{ed}\right.$.). Columbus: Ohio State University Press.

Dörnyei, Z. (2007). Research methods in applied linguistics: Quantitative, qualitative, and mixed methodologies. Oxford: Oxford University Press.

Fitria, T. N. (2019). An analysis of directive speech act found in "koi mil gaya" movie. Journal of Pragmatics Research, 1(2), 89-99.

Fromkin, V., Rodman, R., \& Hyams, N. (2017). An introduction to language (11 ${ }^{\text {th }}$ ed.). Singapore: Cengage Learning, Inc.

Jakob, J. C. (2018). Speech acts in EFL classroom at Islamic senior high school (MAN) 1 Sinjai. Journal of Language and Literature, 18(1), 20-27.

Merdana, Seken, K., \& Putra, N. A. J. (2013). An analysis of speech acts produced by elementary school teachers and students to facilitate teaching and learning at SDN Pringgasela East Lombok. Jurnal Pendidikan Bahasa Inggris Indonesia, 1(43), 1-11.

O’Grady, W., Dobrovolsky, M., \& Aronoff, M. (1989). Contemporary linguistics: An introduction. New York: St. Martin's Press.

Poole, S. C. (1999). An introduction to linguistics. New York: Palgrave.

Yule, G. (1996). Pragmatics. Oxford: Oxford University Press. 